\title{
Association of apolipoprotein E polymorphism with maximal oxygen uptake after exercise training: a study of Chinese young adult
}

\author{
Bo Yu ${ }^{1,2+}$, Wenhua Chen ${ }^{2^{*}+}$, Renwei Wang ${ }^{1}$, Qi Qi ${ }^{2}$, Kunpeng $\mathrm{Li}^{2}$, Wen Zhang ${ }^{2}$ and Huiru Wang ${ }^{3}$
}

\begin{abstract}
Background: Although a few studies have been conducted, it is still unclear whether the apolipoprotein E (APOE) polymorphism is associated with maximal oxygen uptake $\left(\mathrm{VO}_{2 \max }\right)$ after exercise training. The objective of this study was to examine if the APOE gene polymorphisms affect $\mathrm{VO}_{2 \text { max }}$ after exercise training in Chinese young adult.

Methods: A total of 360 Chinese young adult (180 male and 180 female) were recruited into this gender-specific cohorts. Anthropometrics, serum lipids, and $\mathrm{VO}_{2 \max }$ were measured pre and post 6 months of supervised exercise training. Polymerase chain reaction restriction fragment length polymorphism (PCR-RFLP) assay was applied to assess the APOE gene polymorphisms.

Results: $\mathrm{VO}_{2 \max }$ after exercise training increased significantly higher in carriers of $\mathrm{E} 2 / \mathrm{E} 3$ in male [odds ratio $(\mathrm{OR})=0.68$, $95 \%$ confidence interval $(C l)=0.04,1.32 ; P=0.04]$ and female $(\mathrm{OR}=0.62,95 \% \mathrm{Cl}=0.05,1.18 ; P=0.03) . \mathrm{VO}_{2 \max }$ after exercise training increased significantly higher in carriers of $\mathrm{E} 3 / \mathrm{E} 4$ in male $(\mathrm{OR}=0.60,95 \% \mathrm{Cl}=0.09,1.11 ; P=0.02)$ and female ( $\mathrm{OR}=0.62,95 \% \mathrm{Cl}=0.09,1.15 ; P=0.02$ ). No significant differences were found in carriers of $E 2 / E 2, E 2 / E 4, E 3 / E 3$, E4/E4 in either male nor female.

Conclusion: Our study found that APOE gene polymorphism was associated with $\mathrm{VO}_{2 \max }$ levels after exercise training in Chinese young adult. In the future, further experiments will be necessary to confirm this finding and to find the possible mechanism.
\end{abstract}

Keywords: Apolipoprotein E, Gene polymorphism, Maximal oxygen uptake, Exercise training

\section{Introduction}

Physical performance is a complex phenotype influenced by both environmental and genetic factors [1]. Great attention is paid to searching genes underlying athletic performance and variants predisposing to certain sport disciplines [1-4]. Changes in serum lipids with exercise training are often small and individually variable, limiting the role of exercise in treating lipid abnormalities [5]. Maximal oxygen uptake $\left(\mathrm{VO}_{2 \max }\right)$ is traditionally recognized as the gold standard laboratory measure of cardio respiratory fitness, with increasing levels accompanying

\footnotetext{
* Correspondence: wenhuachen@live.cn

${ }^{\dagger}$ Equal contributors

${ }^{2}$ Department of Rehabilitation Medicine, Shanghai First People's Hospital, Shanghai Jiao Tong University, Shanghai 200080, China

Full list of author information is available at the end of the article
}

endurance training and high levels being a pre-requisite for success in endurance events [6].

Apolipoprotein E (apoE), a 299-amino acid, argininerich glycoprotein, is an integral surface component of chylomicrons, very-low-density lipoproteins (VLDL), and some subclasses of high-density lipoproteins (HDL). The $A P O E$ gene, encoded on chromosome 19, exists in three isoforms: E2, E3, and E4, giving six possible genotypes (E2/E2, E2/E3, E2/E4, E3/E3, E3/E4 and E4/E4) [7-9]. $A P O E$ gene polymorphisms seem to have some impact among patients with cardiovascular disease [10-12].

Although a few studies have been conducted, it is still unclear whether the $A P O E$ polymorphism is associated with $\mathrm{VO}_{2 \max }$ after exercise training [13,14]. The objective of this study was to examine if the APOE gene polymorphisms affect $\mathrm{VO}_{2 \max }$ after exercise training in Chinese young adult.

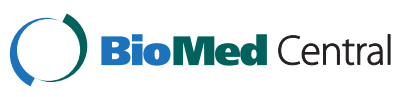

(c) 2014 Yu et al.; licensee BioMed Central Ltd. This is an Open Access article distributed under the terms of the Creative Commons Attribution License (http://creativecommons.org/licenses/by/4.0), which permits unrestricted use, distribution, and reproduction in any medium, provided the original work is properly credited. The Creative Commons Public Domain Dedication waiver (http://creativecommons.org/publicdomain/zero/1.0/) applies to the data made available in this article unless otherwise stated. 


\section{Materials and methods Study population}

A total of 360 Chinese young adult (180 male and 180 female) were recruited into this gender-specific cohorts during the years 2012 to 2013 from Shanghai University of Sport, China. Anthropometrics, serum lipids, and $\mathrm{VO}_{2 \max }$ were measured pre and post 6 months of supervised exercise training. Eligibility criteria included requirements for participants to be healthy, physically inactive, 18-40 years old, to pass a physician-administered physical examination, and to have no significant electrocardiographic abnormalities during a cycle ergometer maximal exercise test. Subjects were considered physically inactive if they participated in vigorous activity fewer than 4 times per month for the prior 6 months. Exclusion criteria included diabetes mellitus, hypertension, hyperlipidemia, or a body mass index (BMI) exceeding $30 \mathrm{~kg} / \mathrm{m}^{2}$. Subjects underwent a progressive, supervised exercise training program. Subjects exercised between $60 \%$ and $85 \%$ of their $\mathrm{VO}_{2 \max }$ based on their predetermined maximal heart rate. $\mathrm{VO}_{2 \max }$ was defined as the average of the 2 highest consecutive 30-second values at peak exercise. Treadmill exercise was the primary mode of training. Subjects were requested to maintain their usual dietary composition throughout the study. The Ethical Committee of the Shanghai University of Sport approved the study protocols, and all participants gave written informed consent according to the Declaration of Helsinki. Each subject received an incremental honorarium for successful completion of the study.

\section{DNA extraction and genotyping}

Venous blood samples were collected in EDTAcontaining tubes from each participant. DNA was extracted from peripheral blood leukocytes using the phenol-chloroform method. Polymerase chain reaction restriction fragment length polymorphism (PCR-RFLP) assay was applied to assess the $A P O E$ gene polymorphisms. Based on the GenBank reference sequence, the PCR primers were as follows: sense, ACAGAATTCGCCCCGGCCTGGTA CAC; antisense, TAAGCTTGGCACGGCTGTCCAAGGA. The amplified PCR products were then digested with $2 \mathrm{U}$ of Hha I (New England BioLabs, Missisauga, ON, Canada) at $37^{\circ} \mathrm{C}$ for 3 hours. The resulting DNA fragments were electrophoresed on 3.5\% agarose gel and visualized under UV light after ethidum staining.

\section{Statistical analysis}

All analyses were performed with Statistical Analyses System (SAS) package (version 8.01; SAS Institute, Cary, $\mathrm{NC}$ ). Univariate analyses of variance were used to compare $A P O E$ groups for differences at baseline and differences in their responses to exercise training. The $P$ value of statistical significance was adjusted by Fisher's exact test where appropriate. A $P$-value was considered significant at a level of $<0.05$. We calculated crude and adjusted odds ratios (OR) and 95\% confidence intervals (CI) for the association between the APOE genotypes and $\mathrm{VO}_{2 \max }$ after exercise training. A chi-square test was used to confirm that the $A P O E$ genotype frequencies were in Hardy-Weinberg equilibrium.

\section{Results}

The demographical and physiological characteristics of the participants were showed in Table 1 . The mean age was $32.8( \pm 11.9)$ years for the male and $31.0( \pm 12.0)$ years for the female. The body weight was $75.1( \pm 15.8) \mathrm{kg}$ for the male and $69.7( \pm 13.1) \mathrm{kg}$ for the female. The BMI was 25.4 $( \pm 5.6) \mathrm{kg} / \mathrm{m}^{2}$ for the male and $26.0( \pm 6.2) \mathrm{kg} / \mathrm{m}^{2}$ for the female. The waist-to-hip ratio (WHR) was $0.81( \pm 0.08)$ for the male and $0.75( \pm 0.06)$ for the female. The $\mathrm{VO}_{2 \max }$ was $2.62( \pm 0.51) \mathrm{L} / \mathrm{min}$ or $34.9( \pm 6.8) \mathrm{mL} / \mathrm{kg} / \mathrm{min}$ for the male and $1.85( \pm 0.36) \mathrm{L} / \mathrm{min}$ or $26.5( \pm 5.2) \mathrm{mL} / \mathrm{kg} / \mathrm{min}$ for the female. The total cholesterol (TC) was $171.4( \pm 6.4) \mathrm{mg} / \mathrm{dL}$ for the male and $163.5( \pm 5.7) \mathrm{mg} / \mathrm{dL}$ for the female. The low-density lipoprotein (LDL-C) was $116.1( \pm 4.8) \mathrm{mg} / \mathrm{dL}$ for the male and $112.2( \pm 4.1) \mathrm{mg} / \mathrm{dL}$ for the female. The HDL-C was $45.1( \pm 1.6) \mathrm{mg} / \mathrm{dL}$ for the male and $49.2( \pm 1.8)$ $\mathrm{mg} / \mathrm{dL}$ for the female. The VLDL-C was $10.2( \pm 0.7) \mathrm{mg} / \mathrm{dL}$ for the male and $12.1( \pm 0.8) \mathrm{mg} / \mathrm{dL}$ for the female. The triglycerides (TG) was $106.5( \pm 13.2) \mathrm{mg} / \mathrm{dL}$ for the male and $89.7( \pm 10.2) \mathrm{mg} / \mathrm{dL}$ for the female (Table 1$)$.

Table 1 The demographical and physiological characteristics of the participants

\begin{tabular}{|c|c|c|}
\hline & Male & Female \\
\hline Total No. & 180 & 180 \\
\hline Age (year) & $32.8 \pm 11.9$ & $31.0 \pm 12.0$ \\
\hline Body weight (kg) & $75.1 \pm 15.8$ & $69.7 \pm 13.1$ \\
\hline BMI $\left(\mathrm{kg} / \mathrm{m}^{2}\right)$ & $25.4 \pm 5.6$ & $26.0 \pm 6.2$ \\
\hline WHR & $0.81 \pm 0.08$ & $0.75 \pm 0.06$ \\
\hline $\mathrm{V}_{2} \max (\mathrm{L} / \mathrm{min})$ & $2.62 \pm 0.51$ & $1.85 \pm 0.36$ \\
\hline $\mathrm{Vo}_{2} \max (\mathrm{mL} / \mathrm{kg} / \mathrm{min})$ & $34.9 \pm 6.8$ & $26.5 \pm 5.2$ \\
\hline $\mathrm{TC}(\mathrm{mg} / \mathrm{dL})$ & $171.4 \pm 6.4$ & $163.5 \pm 5.7$ \\
\hline LDL-C (mg/dL) & $116.1 \pm 4.8$ & $112.2 \pm 4.1$ \\
\hline $\mathrm{HDL}-\mathrm{C}(\mathrm{mg} / \mathrm{dL})$ & $45.1 \pm 1.6$ & $49.2 \pm 1.8$ \\
\hline $\mathrm{HDL}_{2}-\mathrm{C}(\mathrm{mg} / \mathrm{dL})$ & $14.0 \pm 1.0$ & $16.1 \pm 1.1$ \\
\hline $\mathrm{HDL}_{3}-\mathrm{C}(\mathrm{mg} / \mathrm{dL})$ & $31.1 \pm 1.8$ & $33.1 \pm 1.9$ \\
\hline VLDL-C (mg/dL) & $10.2 \pm 0.7$ & $12.1 \pm 0.8$ \\
\hline TG (mg/dL) & $106.5 \pm 13.2$ & $89.7 \pm 10.2$ \\
\hline apo A1 (mg/dL) & $118.4 \pm 3.5$ & $125.3 \pm 3.9$ \\
\hline apo B (mg/dL) & $85.9 \pm 5.8$ & $75.2 \pm 4.9$ \\
\hline
\end{tabular}

BMI, body mass index; WHR, waist-to-hip ratio; $\mathrm{Vo}_{2} \max$, maximal oxygen uptake; TC, total cholesterol; LDL, low-density lipoprotein; HDL, high-density lipoprotein; VLDL, very-low-density lipoprotein; TG, triglycerides. 
$\mathrm{VO}_{2 \max }$ after exercise training increased significantly higher in carriers of E2/E3 in male (OR $=0.68,95 \%$ $\mathrm{CI}=0.04,1.32 ; P=0.04)$ and female $(\mathrm{OR}=0.62,95 \%$ $\mathrm{CI}=0.05,1.18 ; P=0.03$ ) (Tables 2 and 3$). \mathrm{VO}_{2 \max }$ after exercise training increased significantly higher in carriers of E3/E4 in male $(\mathrm{OR}=0.60,95 \% \mathrm{CI}=0.09,1.11 ; P=0.02)$ and female $(\mathrm{OR}=0.62,95 \% \mathrm{CI}=0.09,1.15 ; P=0.02)$ (Tables 2 and 3). No significant differences were found in carriers of E2/E2, E2/E4, E3/E3, E4/E4 in either male nor female.

\section{Discussion}

A lot of studies have been conducted to examine the association of genetic polymorphism and athletic performance. A recent study found that genetic variants of uncoupling proteins- 2 and -3 were associated with $\mathrm{VO}_{2 \max }$ in different sports [1]. A study in 323 Russian athletes and 467 nonathletic controls found that monocarboxylate transporter 1 gene A1470T polymorphism was associated with $\mathrm{VO}_{2 \max }$ [15]. A cohort of 67 Chinese men in Singapore suggested that the angiotensinconverting enzyme $(A C E)$ DD genotype in young adult Chinese males was associated with higher levels of $\mathrm{VO}_{2 \max }$ [16]. The $A C E \mathrm{I} / \mathrm{D}$ polymorphism altered the response of muscle energy supply lines to exercise [17]. AKT1 G205T genotype influenced obesity-related metabolic phenotypes and their responses to aerobic exercise training in older Caucasians [18]. The Genathlete cohort found preliminary evidence that the hypoxia-inducible factor-1alpha Pro582Ser polymorphism may be associated with elite endurance athletes in Caucasian men [19]. A study in 1,423 Russian athletes and 1,132 controls suggested that the likelihood of becoming an elite endurance athlete depended on the carriage of a high number of endurance-related alleles [20]. The A2962G polymorphism of the peroxisome proliferator-activated receptor gamma coactivator 1 alpha (PPARGC1A) gene was associated with $\mathrm{VO}_{2 \max }$ at baseline, as carriers of the $\mathrm{G}$ allele had higher levels of $\mathrm{VO}_{2}$ max than the AA group endurance capacity in Chinese men [21]. The HERITAGE

\begin{tabular}{|c|c|c|c|c|c|}
\hline Genotype & Male & Pre & Post & OR $(95 \% \mathrm{Cl})$ & $P$ \\
\hline E2/E2 & 7 & $2.65(0.57)$ & $2.79(0.51)$ & $0.26(-0.79,1.31)$ & 0.63 \\
\hline E2/E3 & 20 & $2.61(0.50)$ & $2.97(0.56)$ & $0.68(0.04,1.32)$ & 0.04 \\
\hline E2/E4 & 6 & $2.66(0.55)$ & $2.83(0.51)$ & $0.32(-0.82,1.46)$ & 0.58 \\
\hline E3/E3 & 110 & $2.61(0.50)$ & $2.70(0.52)$ & $0.18(-0.09,0.44)$ & 0.19 \\
\hline E3/E4 & 31 & $2.63(0.52)$ & $2.95(0.55)$ & $0.60(0.09,1.11)$ & 0.02 \\
\hline E4/E4 & 6 & $2.67(0.54)$ & $2.80(0.51)$ & $0.25(-0.89,1.38)$ & 0.67 \\
\hline
\end{tabular}

$\mathrm{OR}$, odds ratio; $\mathrm{Cl}$, confidence interval.
Table 3 Frequencies of $A P O E$ gene polymorphisms and maximal oxygen uptake (L/min) pre and post exercise training (mean $\pm S D$ ) in female

\begin{tabular}{cccccc}
\hline Genotype & Female & Pre & Post & OR $(\mathbf{9 5} \% \mathrm{Cl})$ & $\boldsymbol{P}$ \\
\hline E2/E2 & 9 & $1.87(0.36)$ & $1.95(0.39)$ & $0.21(-0.71,1.14)$ & 0.65 \\
E2/E3 & 25 & $1.86(0.38)$ & $2.10(0.40)$ & $0.62(0.05,1.18)$ & 0.03 \\
E2/E4 & 8 & $1.88(0.37)$ & $1.93(0.36)$ & $0.14(-0.84,1.12)$ & 0.78 \\
E3/E3 & 102 & $1.85(0.36)$ & $1.90(0.38)$ & $0.14(-0.14,0.41)$ & 0.34 \\
E3/E4 & 29 & $1.84(0.35)$ & $2.07(0.39)$ & $0.62(0.09,1.15)$ & 0.02 \\
E4/E4 & 7 & $1.86(0.38)$ & $1.97(0.37)$ & $0.29(-0.76,1.35)$ & 0.59 \\
\hline
\end{tabular}

$\mathrm{OR}$, odds ratio; $\mathrm{Cl}$, confidence interval.

Family Study found that peroxisome proliferator-activated receptor-delta (PPARdelta) polymorphisms were associated with physical performance and plasma lipids [22].

The $A P O E$ gene polymorphisms were associated with diseases of the respiratory system and cardiovascular disease. Small lung volumes were prospectively associated with an increased risk for poor cognitive function and dementia in non-carriers of the APOE E4 [23]. Studies in transgenic mice showed that alpha-tocopherol transport in the lung was affected by the $A P O E$ genotype [24]. APOE E4 and cardiorespitatory fitness could interact to influence child adiposity in 8-year-old children from the Tasmanian Infant Health Survey [25]. Although meta-analyses suggest that $A P O E \mathrm{E} 4$ carriers may have a $40-50 \%$ increased coronary artery disease risk, the associations reported in individual studies are highly heterogeneous [26]. In the Tunisian population the APOE E4 appears to be only indirectly involved in the severity of cardiovascular disease [27]. Although the prevalence of the $A P O E$ E4 allele is generally low, there are areas with higher prevalence of the $A P O E \mathrm{E} 4$ allele and a higher incidence of adult ischemic heart disease mortality in Spain [28]. An autopsy study suggested that the risk of developing and dying from cardiovascular disease, including coronary heart disease and cerebrovascular disease, was influenced by the $A P O E$ polymorphism [29]. The APOE E2 genotype might contribute to increased risk of cardiovascular complications in subjects with acromegaly [30]. The APOE genotype predicted cardiovascular endpoints in dialysis patients with type 2 diabetes mellitus [31]. A meta-analysis of 45 studies including 13,940 cases and 16,364 controls found that $A P O E$ gene polymorphisms were associated with essential hypertension [32].

How did the $A P O E$ gene polymorphisms affect $\mathrm{VO}_{2 \max }$ after exercise training? The exact mechanism behind it is still unclear. There is animal evidence that Apo E can affect exercise performance [33]. Controversy exists as to relationship of $A P O E$ polymorphism to the blood lipid response to exercise $[34,35]$. It was unlikely to explain 
the present results. Apo E mRNA is expressed in skeletal muscle and appears to be most abundant at neuromuscular junctions [36]. Therefore the effect of $A P O E$ genotype on exercise capacity may have been mediated by more direct effects on other tissues such as skeletal muscle [14].

There are some limitations to the present study that should be noted. First of all, the present study lacked a control group, since this is a self-control study. Second, the sample size of this study is relatively small, which may not have enough statistical power to explore the real association. Third, we cannot exclude the possibility that some other genetic factor associated with $A P O E$ variants is responsible for the differences in the $\mathrm{VO}_{2 \max }$ response. Finally, these results should be interpreted with caution because the population was only from China, which reduces the possibility of confounding from ethnicity, so it does not permit extrapolation of the results to other ethnic groups.

\section{Conclusion}

In conclusion, our study found that APOE gene polymorphism was associated with $\mathrm{VO} 2 \mathrm{max}$ levels after exercise training in Chinese young adult. In the future, further experiments will be necessary to confirm this finding and to find the possible mechanism.

\section{Competing interest}

The authors declare that they have no competing interests.

\section{Authors' contributions}

BY and WC carried out the molecular genetic studies and drafted the manuscript. RW and QQ carried out the genotyping. KL and WZ participated in the design of the study and performed the statistical analysis. BY, WC and HW conceived of the study, and participated in its design and coordination and helped to draft the manuscript. All authors read and approved the final manuscript.

\section{Authors' information}

Bo Yu and Wenhua Chen are joint first authors.

\section{Acknowledgements}

This study was supported by Key Laboratory of Exercise and Health Sciences (Shanghai University of Sport), Ministry of Education. Thanks are expressed to all coinvestigators, local project coordinators, research assistants, laboratory technicians, and secretaries/administrative assistants.

\section{Author details}

${ }^{1}$ School of Kinesiology, Shanghai University of Sport, Shanghai 200438, China. ${ }^{2}$ Department of Rehabilitation Medicine, Shanghai First People's Hospital, Shanghai Jiao Tong University, Shanghai 200080, China. ${ }^{3}$ Department of Physical Education, Shanghai Jiao Tong University, Shanghai 200240, China.

Received: 4 February 2014 Accepted: 21 February 2014

Published: 27 February 2014

\section{References}

1. Holdys J, Gronek P, Krysciak J, Stanislawski D: Genetic variants of uncoupling proteins-2 and -3 in relation to maximal oxygen uptake in different sports. Acta Biochim Pol 2013, 60:71-75.

2. Bray MS, Hagberg JM, Perusse L, Rankinen T, Roth SM, Wolfarth $B$, Bouchard C: The human gene map for performance and health- related fitness phenotypes: the 2006-2007 update. Med Sci Sports Exerc 2009, 41:35-73.

3. Peeters MW, Thomis MA, Beunen GP, Malina RM: Genetics and sports: an overview of the pre-molecular biology era. Med Sport Sci 2009, 54:28-42.

4. Lippi G, Longo UG, Maffulli N: Genetics and sports. Br Med Bull 2010, 93:27-47.

5. Tran ZV, Weltman A: Differential effects of exercise on serum lipid and lipoprotein levels seen with changes in body weight. A meta-analysis. JAMA 1985, 254:919-924.

6. Bassett DR Jr, Howley ET: Limiting factors for maximum oxygen uptake and determinants of endurance performance. Med Sci Sports Exerc 2000, 32:70-84.

7. Mahfouz RA, Sabbagh AS, Zahed LF, Mahfoud ZR, Kalmoni RF, Otrock ZK, Taher AT, Zaatari GS: Apolipoprotein E gene polymorphism and allele frequencies in the Lebanese population. Mol Biol Rep 2006, 33:145-149.

8. Laskowitz DT, Horsburgh K, Roses AD: Apolipoprotein E and the CNS response to injury. J Cereb Blood Flow Metab 1998, 18:465-471.

9. Boulenouar $\mathrm{H}$, Mediene Benchekor S, Meroufel DN, Lardjam Hetraf SA, Ouhaibi Djellouli H, Hermant X, Grenier-Boley B, Hamani Medjaoui I, Saidi Mehtar N, Amouyel P, Houti L, Meirhaeghe A, Goumidi L: Impact of APOE gene polymorphisms on the lipid profile in an Algerian population. Lipids Health Dis 2013, 12:155.

10. Eichner JE, Dunn ST, Perveen G, Thompson DM, Stewart KE, Stroehla BC Apolipoprotein E polymorphism and cardiovascular disease: a HuGE review. Am J Epidemiol 2002, 155:487-495.

11. Loktionov A, Vorster H, O'Neill IK, Nell T, Bingham SA, Runswick SA, Cummings $\mathrm{JH}$ : Apolipoprotein $\mathrm{E}$ and methylenetetrahydrofolate reductase genetic polymorphisms in relation to other risk factors for cardiovascular disease in UK Caucasians and Black South Africans. Atherosclerosis 1999, 145:125-135.

12. Smalinskiene A, Petkeviciene J, Luksiene D, Jureniene K, Klumbiene J, Lesauskaite V: Association between APOE, SCARB1, PPARalpha polymorphisms and serum lipids in a population of Lithuanian adults. Lipids Health Dis 2013, 12:120.

13. Leon AS, Togashi K, Rankinen T, Despres JP, Rao DC, Skinner JS, Wilmore JH, Bouchard C: Association of apolipoprotein E polymorphism with blood lipids and maximal oxygen uptake in the sedentary state and after exercise training in the HERITAGE family study. Metabolism 2004, 53:108-116.

14. Thompson PD, Tsongalis GJ, Seip RL, Bilbie C, Miles M, Zoeller R, Visich P, Gordon P, Angelopoulos TJ, Pescatello L, Bausserman L, Moyna N: Apolipoprotein $\mathrm{E}$ genotype and changes in serum lipids and maximal oxygen uptake with exercise training. Metabolism 2004, 53:193-202.

15. Fedotovskaya ON, Mustafina L, Popov DV, Vinogradova OL, Ahmetov II: A common polymorphism of the MCT1 gene and athletic performance. Int J Sports Physiol Perform 2014, 9:173-180

16. Zhao B, Moochhala SM, Tham S, Lu J, Chia M, Byrne C, Hu Q, Lee LK Relationship between angiotensin-converting enzyme ID polymorphism and VO(2max) of Chinese males. Life Sci 2003، 73:2625-2630

17. Vaughan D, Huber-Abel FA, Graber F, Hoppeler H, Fluck M: The angiotensin converting enzyme insertion/deletion polymorphism alters the response of muscle energy supply lines to exercise. Eur J Appl Physiol 2013, 113:1719-1729.

18. McKenzie JA, Witkowski S, Ludlow AT, Roth SM, Hagberg JM: AKT1 G205T genotype influences obesity-related metabolic phenotypes and their responses to aerobic exercise training in older Caucasians. Exp Physiol 2011, 96:338-347.

19. Doring F, Onur S, Fischer A, Boulay MR, Perusse L, Rankinen T, Rauramaa R, Wolfarth B, Bouchard C: A common haplotype and the Pro582Ser polymorphism of the hypoxia-inducible factor-1alpha (HIF1A) gene in elite endurance athletes. J Appl Physiol 2010, 108:1497-1500.

20. Ahmetov II, Williams AG, Popov DV, Lyubaeva EV, Hakimullina AM, Fedotovskaya ON, Mozhayskaya IA, Vinogradova OL, Astratenkova IV, Montgomery HE, Rogozkin VA: The combined impact of metabolic gene polymorphisms on elite endurance athlete status and related phenotypes. Hum Genet 2009, 126:751-761.

21. He Z, Hu Y, Feng L, Bao D, Wang L, Li Y, Wang J, Liu G, Xi Y, Wen L, Lucia A: Is there an association between PPARGC1A genotypes and endurance capacity in Chinese men? Scand J Med Sci Sports 2008, 18:195-204.

22. Hautala AJ, Leon AS, Skinner JS, Rao DC, Bouchard C, Rankinen T: Peroxisome proliferator-activated receptor-delta polymorphisms are 
associated with physical performance and plasma lipids: the HERITAGE Family Study. Am J Physiol Heart Circ Physiol 2007, 292:H2498-H2505.

23. Giltay EJ, Nissinen A, Giampaoli S, Kromhout D: Apolipoprotein E genotype modifies the association between midlife lung function and cognitive function in old age. Dement Geriatr Cogn Disord 2009, 28:433-441.

24. Huebbe P, Jofre-Monseny L, Rimbach G: Alpha-tocopherol transport in the lung is affected by the apoE genotype-studies in transgenic apoE3 and apoE4 mice. IUBMB Life 2009, 61:453-456.

25. Ellis JA, Ponsonby AL, Pezic A, Williamson E, Cochrane JA, Dickinson JL, Dwyer T: APOE genotype and cardio-respiratory fitness interact to determine adiposity in 8-year-old children from the Tasmanian Infant Health Survey. PLoS One 2011, 6:e26679.

26. Minihane AM, Jofre-Monseny L, Olano-Martin E, Rimbach G: ApoE genotype, cardiovascular risk and responsiveness to dietary fat manipulation. Proc Nutr Soc 2007, 66:183-197.

27. Bahri R, Esteban E, Moral P, Hassine M, Ben Hamda K, Chaabani H: Apolipoprotein gene polymorphisms and plasma levels in healthy Tunisians and patients with coronary artery disease. Lipids Health Dis 2008, 7:46.

28. Garces C, Cantos M, Benavente M, Granizo JJ, Cano B, Viturro E, De Oya M: Variations in APOE genotype distribution in children from areas with different adult cardiovascular disease mortality in Spain. Hum Biol 2004, 76:615-621

29. Kumar NT, Liestol K, Loberg EM, Reims HM, Brorson SH, Maehlen J: The apolipoprotein E polymorphism and cardiovascular diseases-an autopsy study. Cardiovasc Pathol 2012, 21:461-469.

30. Bozok Cetintas V, Zengi A, Tetik A, Karadeniz M, Ergonen F, Kucukaslan AS, Tamsel S, Kosova B, Sahin SB, Saygili F, Eroglu Z: Does Apolipoprotein E genotype affect cardiovascular risk in subjects with acromegaly? Endocrine 2012, 41:465-472.

31. Winkler K, Hoffmann MM, Krane V, Marz W, Drechsler C, Wanner C: Apolipoprotein E genotype predicts cardiovascular endpoints in dialysis patients with type 2 diabetes mellitus. Atherosclerosis 2010, 208:197-202.

32. Stoumpos S, Hamodrakas SJ, Anthopoulos PG, Bagos PG: The association between apolipoprotein $\mathrm{E}$ gene polymorphisms and essential hypertension: a meta-analysis of 45 studies including 13,940 cases and 16,364 controls. J Hum Hypertens 2013, 27:245-255.

33. Maxwell AJ, Schauble E, Bernstein D, Cooke JP: Limb blood flow during exercise is dependent on nitric oxide. Circulation 1998, 98:369-374.

34. Taimela S, Lehtimaki T, Porkka KV, Rasanen L, Viikari JS: The effect of physical activity on serum total and low-density lipoprotein cholesterol concentrations varies with apolipoprotein E phenotype in male children and young adults: The Cardiovascular Risk in Young Finns Study. Metabolism 1996, 45:797-803

35. St-Amand J, Prud'homme D, Moorjani S, Nadeau A, Tremblay A, Bouchard C, Lupien PJ, Despres JP: Apolipoprotein E polymorphism and the relationships of physical fitness to plasma lipoprotein-lipid levels in men and women. Med Sci Sports Exerc 1999, 31:692-697.

36. Akaaboune M, Villanova M, Festoff BW, Verdiere-Sahuque M, Hantai D: Apolipoprotein $\mathrm{E}$ expression at neuromuscular junctions in mouse, rat and human skeletal muscle. FEBS Lett 1994, 351:246-248.

\section{Submit your next manuscript to BioMed Central and take full advantage of:}

- Convenient online submission

- Thorough peer review

- No space constraints or color figure charges

- Immediate publication on acceptance

- Inclusion in PubMed, CAS, Scopus and Google Scholar

- Research which is freely available for redistribution 